\title{
Disminución de la agudeza visual en distrofia macular anular macular dystrophy
}

René Hernán Parada-Vásquez*

Becario de segmento anterior, Instituto de la Visión, Nuevo León, México

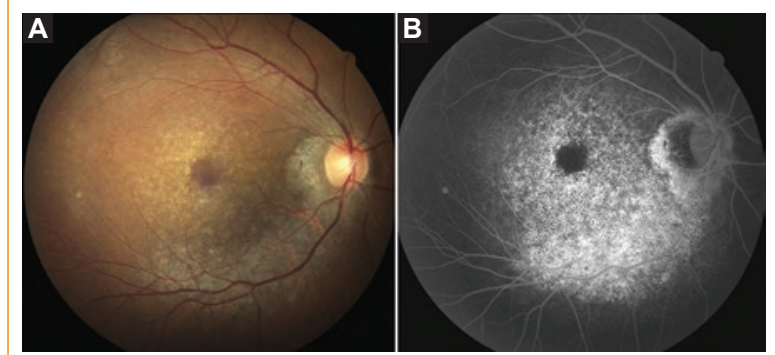

Figura 1. A: fotografía a color de fondo del ojo derecho, se aprecia cambios de coloración del epitelio pigmentario de la retina a nivel perimacular. B: angiografía fluoresceínica, en tiempo arteriovenoso medio, se evidencian áreas de atrofia a nivel del epitelio pigmentario perimacular, con extenso defecto de ventana en la arcada temporal inferior.
En la angiografía fluoresceínica: se evidencian áreas de atrofia del epitelio pigmentario perimacular, con distribución anormal del mismo, presentando defectos de ventana que coinciden con la distribución anormal de la lipofuscina en la autofluorescencia (Fig. 1B).

\section{Responsabilidades éticas}

Protección de personas y animales. El autor declara que para esta investigación no se han realizado experimentos en seres humanos ni en animales.

Confidencialidad de los datos. El autor declara que ha seguido los protocolos de su centro de trabajo sobre la publicación de datos de pacientes.

Derecho a la privacidad y consentimiento informado. El autor ha obtenido el consentimiento informado de los pacientes y/o sujetos referidos en el artículo. Este documento obra en poder del autor de correspondencia.

\section{Financiamiento}

El autor no recibió patrocinio para llevar a cabo este artículo.

\section{Conflicto de intereses}

El autor declara no tener ningún conflicto de intereses. temporales, más evidente a nivel inferior (Fig. 1A).

Paciente femenina de 32 años, que presenta dismiojo derecho: 20/80 y del ojo izquierdo: 20/60. En la fundoscopia de ambos ojos se aprecia: disco óptico definido, cambios de coloración del epitelio pigmentario de la retina a nivel perimacular, así como en las arcadas 